\title{
Hubungan antara Lama Ketuban Pecah Dini dengan Skor Apgar Neonatus di RSUP Dr. M Djamil Padang
}

\author{
Hanifa Hafni ${ }^{1}$, Syahredi SA ${ }^{2}$, Finny Fitry Yani ${ }^{3}$
}

\begin{abstract}
Abstrak
Ketuban Pecah Dini (KPD) merupakan keadaan dimana pecahnya selaput ketuban setiap saat sebelum ada tanda persalinan. KPD merupakan salah kehamilan beresiko tinggi, karena semakin lama KPD akan semakin meningkatkan resiko morbiditas pada bayi. Skor Apgar merupakan metode yang digunakan untuk menilai bayi baru lahir. Tujuan penelitian ini adalah menentukan hubungan antara lama KPD dan skor apgar neonatus. Penelitian analitik ini menggunakan desain penelitian cross sectional study. Populasi penelitian adalah seluruh rekam medik RSUP Dr. M. Djamil Padang yang didiagnosis sebagai kasus ketuban pecah dini selama periode Januari 2010 sampai Desember 2011. Sampel diambil dari seluruh populasi yang memenuhi kriteria restriksi secara total sampling, sehingga didapatkan 164 sampel yang memenuhi kriteria. Hasil penelitian ini menemukan insiden KPD di RSUP Dr. M. Djamil Padang yaitu 8,1\%. Pasien dengan KPD kurang dari 6 jam didapatkan skor Apgar baik 95 kasus (57,9\%) dan skor apgar buruk 4 kasus (2,4\%), sedangkan KPD lebih dari 6 jam didapatkan skor apgar baik 5 kasus (3\%) dan skor Apgar buruk 60 kasus (36,6\%). Analisis bivariat menggunakan uji chi-square diperoleh nilai $p=0.485(p>0.05)$. Simpulan penelitian ini adalah tidak terdapat hubungan antara lama KPD dengan skor Apgar neonatus di RSUP Dr. M. Djamil Padang.
\end{abstract}

Kata kunci: ketuban pecah dini, skor Apgar

\begin{abstract}
Keywords: premature rupture of membranes, Apgar score
\end{abstract}

Premature Rupture Of Membranes (PROM) is defined as rupture of membranes before the onset of labor. $P R O M$ is one of the high risk pregnancies, because the longer PROM would increase the risk of morbidity in infants. Apgar score is a method to evaluate condition of newborn infant. The objective of this study was to determine the relation between the length of PROM and Apgar score in neonates at RSUP Dr. M. Djamil Padang. This was an analytic research with cross sectional design. Population were all medical record in RSUP Dr. M. Djamil with PROM from January 2010 until December 2011. The samples were taken from all population that have a restriction criteria using total sampling technic, so only 164 samples were suitable The results found that the incidence of PROM in RSUP Dr. M. Djamil Padang is $8.1 \%$. The result for patient with PROM $\leq 6$ hours with good Apgar is 95 case (57.9\%) and with bad Apgar is 4 case (2.4\%), PROM >6 hours with good Apgar is 60 case (36.6\%) and with bad Apgar is 5 case (3\%). The bivariate analysis by chi-square was $p$ value $=0.485(p>0.05)$. The conclusion is no correlation between the length of PROM and Apgar Score in neonates at RSUP Dr. M. Djamil Padang.

\section{PENDAHULUAN}

Keberhasilan suatu pelayanan kesehatan tercermin dari penurunan angka kematian ibu dan bayi sampai batas terendah sesuai dengan kondisi dan situasi daerah tersebut. World Health Organization 
(WHO) dalam Millenium Development Goals (MDGs) menargetkan penurunan mortalitas ibu (MDG 5) sebesar $75 \%$ dan penurunan mortalitas anak (MDG 4) sebesar dua pertiga khususnya anak usia dibawah 5 tahun, selama rentang tahun 1990 sampai tahun 2015. Data angka kematian ibu yang tercatat hingga tahun 2008 hanya mengalami penurunan sekitar 34\% dari tahun 1990, sedangkan angka kematian anak usia dibawah 5 tahun dari 1990 hingga 2009 mengalami penurunan dari 89 menjadi 60 per 1000 kelahiran hidup, keduanya masih jauh dari angka yang ditargetkan. ${ }^{1} \mathrm{Di}$ Indonesia sendiri, Survei Demografi Kesehatan Indonesia (SDKI) 2007 melaporkan proporsi kematian bayi sebesar 34 per seribu kelahiran hidup. ${ }^{2}$

Kehamilan yang meningkatkan kemungkinan morbiditas dan mortalitas pada janin ataupun neonatus disebut juga dengan kehamilan beresiko tinggi. Ada 10\% - 20\% ibu hamil dengan resiko tinggi tersebut dihubungkan dengan kasus morbiditas dan mortalitas perinatal, salah satunya yaitu ibu hamil dengan ketuban pecah dini. ${ }^{3}$ Ketuban Pecah Dini (KPD) didefinisikan sebagai peristiwa pecahnya selaput ketuban selama tahap manapun sebelum persalinan dimulai. ${ }^{4}$ Angka kejadian Ketuban pecah dini sekitar $6-12 \%$ dari seluruh kehamilan. ${ }^{5}$ Penelitian di Kenya, angka kematian perinatal yaitu 118 per 1000 kelahiran dengan 2,9\% nya disebabkan ketuban pecah dini. ${ }^{6}$ RSUP Dr. M. Djamil Padang didapatkan angka kejadian KPD sebesar $3,87 \%{ }^{7}$ Kelainan ini dianggap penting karena angka kejadian ketuban pecah dini yang cukup tinggi sehingga morbiditas dan mortalitas ibu dan anak yang akan meningkat.

Ketuban pecah dini merupakan salah satu faktor penyebab asfiksia neonatorum dan infeksi. Masa laten atau jarak antara pecahnya ketuban dengan persalinan berperan penting dalam peningkatan insiden infeksi sekunder, selain itu pecahnya ketuban akan terjadi oligohidramnion yang akan menyebabkan tertekannya tali pusat sehingga terjadi asfiksia pada neonatus. ${ }^{8}$

Salah satu indikator yang digunakan untuk menilai kondisi postnatal yang lahir dengan ketuban pecah dini adalah skor Apgar.Patokan klinis untuk skor Apgar terdiri atas frekuensi jantung, usaha nafas, tonus otot, reflex dan warna. Penilaian untuk skor Apgar dilakukan 1 menit setelah bayi lahir lengkap, dan selanjutnya dilakukan 5 menit berikutnya. ${ }^{3}$

Berdasarkan latar belakang tersebut maka perlu dikaji kasus ketuban pecah dini di Bagian Obstetrik dan Ginekologi di RSUP Dr. M. Djamil Padang dengan Skor Apgar pada neonatus.

\section{METODE}

Penelitian dilakukan di Sub bagian Rekam Medik (Medical Record) RSUP Dr. M. Djamil Padang. Pelaksanaan penelitian dilakukan selama 14 bulan (Oktober 2011- Janari 2013). Sampel penelitian adalah seluruh rekam medik yang didiagnosis sebagai ketuban pecah dini di subbagian rekam medis RSUP Dr. M. Djamil Padang periode 1 Januari 2010 - 31 Desember 2011 yang memenuhi kriteria inklusi dan eksklusi. Sampel dalam penelitian ini sebanyak 164 sampel. Metode pengambilan sampelnya adalah dengan cara total sampling. Data yang diperoleh dianalisis dengan uji chi-square pada tingkat pemaknaan $p<0,05$.

\section{HASIL}

Berdasarkan penelitian yang telah dilakukan di bagian Obstetri dan Ginekologi sub bagian rekam medik RSUP Dr. M. Djamil Padang diperoleh 230 kejadian ketuban pecah dini (KPD) dari 2839 persalinan Hal ini berarti insiden KPD sebesar $8,10 \%$ selama kurun waktu 1 Januari 2010 hingga 31 Desember 2011.

Tabel 1. Distribusi frekuensi subjek penelitian berdasarkan lama KPD

\begin{tabular}{ccc}
\hline Ketuban pecah dini & Frekuensi & Persentase (\%) \\
\hline$\leq 6$ jam & 99 & 60,4 \\
$>6$ jam & 65 & 39,6 \\
Total & 164 & 100 \\
\hline
\end{tabular}


Pada Tabel 1 dapat dilihat bahwa ibu hamil dengan lama ketuban pecah dini $\leq 6$ jam berjumlah 99 orang $(60,4 \%)$, sedangkan ibu hamil dengan lama ketuban pecah dini $>6$ jam 65 Orang $(39,6 \%)$. Di Bagian obstetrik Ginekologik RSUP Dr. M. Djamil Padang mempunyai protap pasien yang hamil aterm yang mengalami ketuban pecah dini kurang dari 6 jam akan ditunggu hingga 6 jam untuk diterminasi jika lebih dari 6 jam akan langsung diterminasi.

Pada penelitian ini didapatkan ibu hamil dengan ketuban pecah dini yang kurang sama 6 jam lebih banyak daripada ibu hamil dengan ketuban pecah dini yang lebih dari 6 jam, hasilnya berturutturut sebanyak 99 orang $(60,4 \%)$ dan 65 Orang $(39,6 \%)$. Pada penelitian ini juga didapatkan lama KPD terendah adalah 10 menit dan terlama adalah 48 jam.

Tabel 2. Distribusi frekuensi subjek penelitian berdasarkan skor Apgar

\begin{tabular}{ccc}
\hline Skor Apgar & Frekuensi & Persentase (\%) \\
\hline$<7$ & 9 & 5.5 \\
$\geq 7$ & 155 & 94.5 \\
Total & 164 & 100.0 \\
\hline
\end{tabular}

Pada Tabel 2 dapat dilihat bahwa hanya ditemukan 9 orang $(5,5 \%)$ bayi yang dilahirkan memiliki skor Apgar $<7$ dan dikategorikan skor Apgar buruk, sedangkan 155 bayi (94,5\%) dilahirkan dengan skor Apgar $\geq 7$ dikategorikan sebagai skor Apgar baik.

Skor Apgar bayi terendah dari ibu dengan KPD yang dijadikan sebagai subjek pada penelitian adalah 2 dan tertinggi adalah 10.

Hubungan antara lama ketuban pecah dini dengan skor Apgar neonatus diatas, maka dilakukan analisis bivariat dengan menggunakan uji chi-square. Hubungan lama ketuban pecah dini dengan skor Apgar neonatus dapat dilihat pada tabel berikut
Tabel 3. Analisis bivariat hubungan antara lama KPD dengan Skor Apgar pada bayi di RSUP Dr. M. Djamil Padang periode Januari 2010 - 31 Desember 2011

\begin{tabular}{|c|c|c|c|}
\hline \multirow[t]{2}{*}{ Kriteria } & \multicolumn{2}{|c|}{ Apgar } & \multirow[t]{2}{*}{ Total } \\
\hline & $<7$ & $\geq 7$ & \\
\hline Lama KPD & $\begin{array}{c}5 \\
(3 \%)\end{array}$ & $\begin{array}{c}60 \\
(36,6 \%)\end{array}$ & $\begin{array}{c}65 \\
(39,5 \%)\end{array}$ \\
\hline 6 jam & $\begin{array}{c}4 \\
(2,4 \%)\end{array}$ & $\begin{array}{c}95 \\
(57,9 \%)\end{array}$ & $\begin{array}{c}99 \\
(60,4 \%)\end{array}$ \\
\hline Total & $\begin{array}{c}9 \\
(5,5 \%)\end{array}$ & $\begin{array}{c}55 \\
(94,5 \%)\end{array}$ & $\begin{array}{c}28 \\
(100 \%)\end{array}$ \\
\hline
\end{tabular}

Hasil uji statistik dengan tes chi-square didapatkan nilai expected count yang kurang dari 5 sebanyak $25 \%$, dengan demikian tabel $2 \times 2$ ini tidak layak diuji dengan chi-square, oleh karena itu dipakai uji alternatif yaitu uji Fisher, sehingga didapatkan nilai signifikannya $(p)$ adalah $0,485(p>0,05)$, artinya tidak terdapat hubungan antara lama ketuban pecah dini dan skor apgar neonatus.

\section{PEMBAHASAN}

Hubungan lama ketuban pecah dini dan skor apgar pada bayi memang telah dilaporkan pada beberapa penelitian. Pada penelitian yang dilakukan oleh Rahayu (2009) di RS daerah Cepu Surakarta didapatkan adanya hubungan antara lamanya ketuban pecah dini dengan skor Apgar pada neonatus dengan nilai $p 0,003(p<0,05) .{ }^{9}$ Penelitian yang dilakukan oleh Meisha (2010) di RS Bhakti Yudha Depok terdapat hubungan antara ketuban pecah dini dengan skor Apgar neonatus dengan nilai $p$ 0,011 $(p<0,05),{ }^{10}$ namun pada kedua penelitian ini interval waktu yang digunakan berbeda dengan penelitian ini, yaitu kurang dari 12 jam dan lebih sama 12 jam.

Ada juga terdapat faktor lain yang mempengaruhi skor Apgar, yaitu proses persalinan (seksio sesaria, pervaginam), obat-obatan yang dikonsumsi ibu, serta kondisi kardiorespirasi dan neurologis bayi. ${ }^{11,12}$ 
Dalam penilaian skor Apgar bisa terjadi positif palsu (tidak ada asidosis atau hipoksia janin; Apgar rendah) ataupun negatif palsu (asidosis; Apgar normal). Hal-hal yang bisa menyebabkan terjadinya positif palsu seperti imaturitas, analgetik, narkotik, sedatif, magnesium sulfat, trauma serebral akut, persalinan yang sangat cepat, neuropati kongenital, anomali SSP, miopati kongenital, trauma medula spinalis, anomali paru, obstruksi jalan napas, pneumonia kongenital dan episode sebelum asfiksia janin. Hal-hal yang mempengaruhi terjadinya negatif palsu seperti ibu yang asidosis, kadar katekolamin janin tinggi dan beberapa bayi cukup bulan. ${ }^{3}$

Kebiasaan hidup ibu hamil dan keadaan sosial ekonomi keluarga sebagai faktor eksternal ibu hamil yang turut mempengaruhi juga belum bisa disingkirkan sebagai faktor perancu dalam penelitian ini. Status sosial ekonomi bisa berpengaruh terhadap kejadian ketuban pecah dini karena bertanggung jawab terhadap nutrisi yang dikonsumsi ibu hamil, asuhan antenatal yang memadai dan timbulnya komplikasi selama kehamilan. ${ }^{13}$

\section{SIMPULAN}

Tidak ditemukan adanya hubungan lama ketuban pecah dini dengan skor apgar neonatus di RSUP Dr. M. Djamil Padang.

\section{UCAPAN TERIMA KASIH}

Terima kasih kepada semua pihak yang telah membantu dalam pelaksanaan penelitian ini.

\section{DAFTAR PUSTAKA}

1. The Millenium Development Goals Report 2011. United states; 2011.

2. Departemen Kesehatan Republik Indonesia. Survei demografi kesehatan Indonesia (SKDI). Jakarta: Departemen Kesehatan Republik Indonesia; 2007.

3. Nelson WE. IImu Kesehatan anak (terjemahan). Edisi ke-15. Jakarta: EGC; 2010.

4. Cunningham FG, Gant NF, Leveno KJ, Gilstrap LC, Hauth JC, Wenstrom KD. Obstetri William (terjemahan). Edisi ke-21 Vol 1 dan 2, Jakarta: EGC; 2006.

5. Cammu H, Verlaennen H, Derde MP. Premature Rupture of Membranes at Terms: A Hazard?. American College of Obstetricians and Gynecologists. 1990;76(4):671-4.

6. Weiner, Renay, Ronsmans A, Ed Dorman, Jilo H, Muhoro A, Shulman C. Labour complications remain the most important risk factors for perinatal mortality in rural Kenya. Bulletin of the World Health Organization. 2003;81(7).

7. Shamsuddin SB. Hubungan paritas dan usia ibu terhadap terjadinya ketuban pecah dini di bagian obstetri dan ginekologi BLU rumah sakit Dr. M. Djamil Padang tahun 2004-2005. Padang: Fakultas Kedokteran Universitas Andalas; 2006.

8. Prawirohardjo S. Ilmu kebidanan. Edisi ke-4. Jakarta: PT Bina Pustaka Sarwono Prawirohardjo; 2009.

9. Rahayu ASE. Hubungan antara lama ketuban pecah dini terhadap nilai Apgar pada kehamilan aterm di badan rumah sakit daerah Cepu. Surakartara: Fakultas Kedokteran Universitas Muhammadiyah; 2009.

10. Meisha. Hubungan antara lamanya periode laten pada ketuban pecah dini pada kehamilan aterm terhadap nilai Apgar pada persalinan pervaginam di RS Bhakti Yudha Depok periode 2008-2010. Jakarta: Universitas Pembangunan Nasional Veteran; 2010.

11. Rogers JF, Graves WL. Risk factors associated with low Apgar scores in a low-income population. NCBI.1993;205.

12. American college of Obstetricians and Gynecologist, Committee on Obstetric Practice. The Apgar Score. 2006; No.333.

13. Akter S, Akter R, Rashid M. Preterm Prelabour Rupture of the membrane and feto-maternal outcome, an Observational Study. Journal of Bangladesh College of Physician and Surgeons. 2010;28:17-23. 